\title{
Pengaruh Foot Massage dan Pergerakan Sendi Ekstremitas Bawah terhadap Nilai Ankle Brachial Index (ABI) pada Pasien DM Tipe 2 di Wilayah Kerja Puskesmas Peukan Baro, Kab. Pidie
}

\author{
Isni Hijriana ${ }^{1, *}$, Miniharianti $^{2}$ \\ ${ }^{1}$ STIKes Jabal Ghafur, Sigli, 24151, Indonesia \\ ${ }^{2}$ STIKes Jabal Ghafur, Sigli, 24151, Indonesia \\ ${ }^{1}$ hijrianaisni@gmail.com*; ${ }^{2}$ mini.harianti@gmail.com \\ * corresponding author
}

\section{ARTICLE INFO}

Article history

23-08-2021

10-09-2021

30-09-2021

Keywords

Foot massage

Lower joint movement

Ankle Brachial Index (ABI) DM type 2

\begin{abstract}
Diabetes mellitus Type 2 (DM Type 2) is the risk factor for the incidence of vascular. Diabetic neuropathy and/or peripheral arterial disease, are common and represent major causes of morbidity and mortality in people with diabetes. Physical exercises is have been done to prevent from diabetes complication, and one of them is by foot massage and lower extremity joint movement. Measuring the value of ankle brachial index (ABI) is one of non-invasive actions to evaluate the risk for peripheral vascular in primary treatment. The objective of this research was to determine the influence of foot massage and joint movement exercise on ABI value in DM Type 2 patients. The research used quasi experiment method with pretest-posttest group design and two intervention groups. The samples were 40 DM Type 2 patients, taken by using consecutive sampling technique. Intervention was given by conducting foot massage and lower extremity joint movement exercise. Wilcoxon Signed Ranks statistic test showed that there was the difference in pre and post intervention of foot massage and lower extremity joint movement from ABI value, for $(\mathrm{p}=0.00)$. The conclusion was that foot massage and lower extremity joint movement exercise could increase ABI value if it was done continuously. It could also increase blood flow to artery. This research could bean input for nursing care to make physical exercises such as foot massage and lower extremity joint movement as prevention from risk of longterm Complications in DM Type 2 patients.
\end{abstract}

\section{Pendahuluan}

Diabetes merupakan suatu gangguan metabolisme kronis dengan multi etiologi yang ditandai dengan tingginya kadar gula darah disertai dengan gangguan metabolisme karbohidrat, lipid dan protein sebagai akibat dari insufisiensi fungsi insulin. Penderita diabetes berisiko tinggi terkena penyakit lain seperti jantung, penyakit arteri perifer dan serebrovaskular, obesitas, katarak, disfungsi ereksi, dan liver non-alkoholik [1].

Diabetes melitus merupakan pencetus yang berkontribusi terhadap kejadian penyakit sehingga diperlukan pengendalian untuk mencegah dan menurunkan tingkat fatalitas, beberapa faktor resiko yang dapat dimodifikasi yaitu berat badan lebih, obesitas abdminal/sentral, kurangnya aktifitas latihan fisik, hipertensi, dislipidemia, diet tidak sehat dan tidak seimbang (tinggi kalori), kondisi prediabetes yang ditandai dengan toleransi glukosa terganggu (TGT 140-199 mg/dl) atau gula darah puasa terganggu (GDPT < $140 \mathrm{mg} / \mathrm{dl}$ ) dan merokok. Pada Riskedas 2018, prevalensi diabetes mellitus pada perempuan lebih tinggi dibandingkan laki-laki dengan perbandingan $1.78 \%$ 
terhadap $1.21 \%$, dan pada riskesdas 2013 prevalensi pada perempuan terhadap laki-laki sebesar 1.7 $\%$ terhadap $1.4 \%$. Pada lima tahun terakhir, prevalensi pada perempuan menunjukkan sedikit peningkatan, sedangkan prevalensi pada lakilaki menunjukkan penurunan [2].

Data epidemiologi dan patalogis menunjukkan bahwa diabetes merupakan faktor resiko terjadinya penyakit vaskular pada laki-laki dan perempuan, hal ini berhubungan dengan disfungsi makrovaskular (akibat gangguan pembuluh darah besar) dan mikrovaskular (akibat gangguan pembuluh darah kecil) [3]. Setiap pasien dengan diabetes perlu dilakukan pemeriksaan komprehensif kaki minimal setiap satu tahun meliputi inspeksi, perabaan pulsasi arteri dorsalis pedis dan tibialis posterir, dan pemeriksaan neuropati sensorik. Kaki diabetik dengan ulkus merupakan komplikasi diabetes yang sering terjadi. Ulkus kaki diabetik adalah luka kronik pada daerah dibawah pergelangan kaki, yang meningkatkan morbiditas, mortalitas, dan mengurangi kualitas hidup pasien [4].

Pendidikan dan dukungan terhadap manajemen diri pasien diabetes sangat penting untuk mencegah komplikasi akut dan mengurangi komplikasi jangka panjang.Pengenalan dan pengobatan dini pada pasien diabetes dapat mencegah resiko ulkus dan amputasi. Penyakit arteri perifer(PAD) adalah penyebab morbiditas dan mortalitas yang paling umum terjadi pada penderita diabetes [5].Pengukuran nilai ankle brachial index (ABI) merupakan salah satu tindakan non invasif untuk mendeteksi penyakit arteri perifer (PAD), nilai $A B I$ yang rendah diprediksi sebagai variabel prediktif pada penyakit kardiovaskular (CVD), Sedangkan nilai ABI yang tinggi berkaitan dengan kalsifikasi arteri medial [6].

Penelitian tentang pengaruh latihan fisik terhadap ABI menunjukkan adanya peningkatan nilai $\mathrm{ABI}$ secara signifikan pada kelompok intervensi, peningkatan nilai ABI ini berhubungan dengan penurunan $\mathrm{HbA}_{1} \mathrm{c}$ dan tekanan darah sistol dan diastol sehingga tersebut memiliki peranan yang sangat penting dalam pencegahan terjadinya penyakit arteri perifer khususnya pasien DM Tipe 2 [7]. Penelitian lain juga menunjukkan bahwa pengaruh pijat kaki yang signifikan terhadap proses sensorik dan neuropatik,.Semakin baik nilai ABI maka semakin rendah tingkat perifer neuropati diabetik yang dialami oleh pasien DM [8].

\section{Metode}

Jenis penelitian ini adalah desain quasi-eksperiment jenis pre-test and post-test group design, dengan dua kelompok intervensi dengan masing-masing kelompok diberikan intervensi yang berbeda yaitu kelompok yang mendapatkan intervensi foot massage dan kelompok yang mendapatkan intervensi pergerakan sendi ekstremitas bawah. Desain ini bertujuan atau menentukan sejauh mana pengaruh atau efektivitas tindakan foot massage dan pergerakan sendi ekstremitas bawah terhadap nilai ankle brachial index (ABI). Penelitian ini dilakukan di wilayah kerja puskesmas Peukan Baro, Kabupaten Pidie pada bulan Juli-Agustus 2021. Total sampel dalam penelitian ini adalah 40 pasien DM Tipe 2 dengan masing-masing kelompok intervensi terdiri dari 20 responden. Pengambilan sampel dengan menggunakan teknik consecutive sampling. Alat yang digunakan untuk mengukur ABI yaitu tensimeter aneroid dan Dopller Probe $8 \mathrm{MHz}$.

Intervensi yang akan diberikan kepada responden sebelumnya telah mendapatkan persetujuan etik dan mendapatkan surat keterangan lolos kaji etik dari Fakultas Keperawatan Universitas Sumatera Utara. Sebelum diberikan intervensi responden dilakukan pengukuran nilai ABI terlebih dahulu pada tahap Pre Test. Intervensi foot massagedan pergerakan sendi dilakukan selama 14 hari. Foot massage dilakukan oleh keluarga responden yang sebelumnya telah mendapatkan dan pengawasan oleh asisten peneliti, serta pergerakan sendi yang terdiri dari beberapa gerakan ROM yang dilakukan secara aktif oleh responden. Setelah Periode intervensi selesai maka dilakukan pengukuran nilai ABI kembali pada tahap Post Test. Tahap selanjutnya setelah pengumpulan data yaitu tabulasi data yang kemudian akan diuji normalitas data. Pada penelian ini data tidak berdistribusi normal sehingga uji bivariat yang digunakan yaitu Uji Wilcoxon Signed Ranks test. 


\section{Hasil dan Diskusi}

\subsection{Hasil Analisis Sebelum (Pretest) dan Sesudah (Postest) pada Kelompok Intervensi Foot Massage}

Tabel 1. Deskripsi Frekuensi Nilai KGDs pada Pasien Diabetes

\begin{tabular}{clcccc}
\hline No & Nilai KGDs & Mean & Median & SD & Min - Maks \\
\hline 1 & Sebelum & 359.30 & 340.00 & 86,86 & $223-561$ \\
2 & Sesudah & 298.65 & 272.00 & 104.482 & $180-450$ \\
& Total & $\mathrm{N}=20$ \\
\hline
\end{tabular}

Tabel 1 menunjukkan nilai KGDs pada pasien diabetes pada periode pretest atau sebelum dan sesudah diberikan intervensi. Hasil pengukuran KGDs sebelum intervensi menunjukkan ratarata nilai KGDs adalah $359.30 \mathrm{mg} / \mathrm{dL}$, median $340 \mathrm{mg} / \mathrm{dL}$, standar deviasi 86.86, dengan KGDs terendah yaitu $223 \mathrm{mg} / \mathrm{dL}$ dan nilai tertinggi $561 \mathrm{mg} / \mathrm{dL}$. Sedangkan Hasil pengukuran KGDs sesudah intervensi menunjukkan rata-rata nilai KGDs adalah $298.65 \mathrm{mg} / \mathrm{dL}$, median 272.00 $\mathrm{mg} / \mathrm{dL}$, standar deviasi 104.482, dengan KGDs terendah yaitu $180 \mathrm{mg} / \mathrm{dL}$ dan nilai tertinggi 450 $\mathrm{mg} / \mathrm{dL}$.

Tabel 2. Deskripsi Nilai ABI pada Pasien Diabetes

\begin{tabular}{clcccc}
\hline No & \multicolumn{1}{c}{ Nilai ABI } & Mean & Median & SD & Min - Maks \\
\hline 1 & Sebelum & 0.91 & 0.92 & 0.04 & $0.86-1.04$ \\
2 & Sesudah & 0.99 & 1.00 & 0.05 & $0.93-1.10$ \\
& Total & & $\mathrm{N}=20$ \\
\hline
\end{tabular}

Tabel 2 menunjukkan nilai ABI pasien diabetes pada periode pretest atau sebelum dan sesudah diberikan intervensi. Hasil pengukuran menunjukkan rata-rata nilai ABI sebelum intervensi yaitu 0.91 , median 0.92 , standar deviasi 0.04 , dengan nilai terendah pada 0.86 , dan nilai tertinggi 1.04. Sedangkan Hasil pengukuran sesudah diberikan intervensi menunjukkan bahwa ratarata nilai $\mathrm{ABI} 0.99$, median 1.00 , standar deviasi 0.05 , dengan nilai terendah pada 0.93 , dan nilai tertinggi 1.10 .

Bagan 1. Deskripsi Nilai ABI Sebelum Intervensi(Pre Test) Foot Massage pada Pasien DM Tipe 2

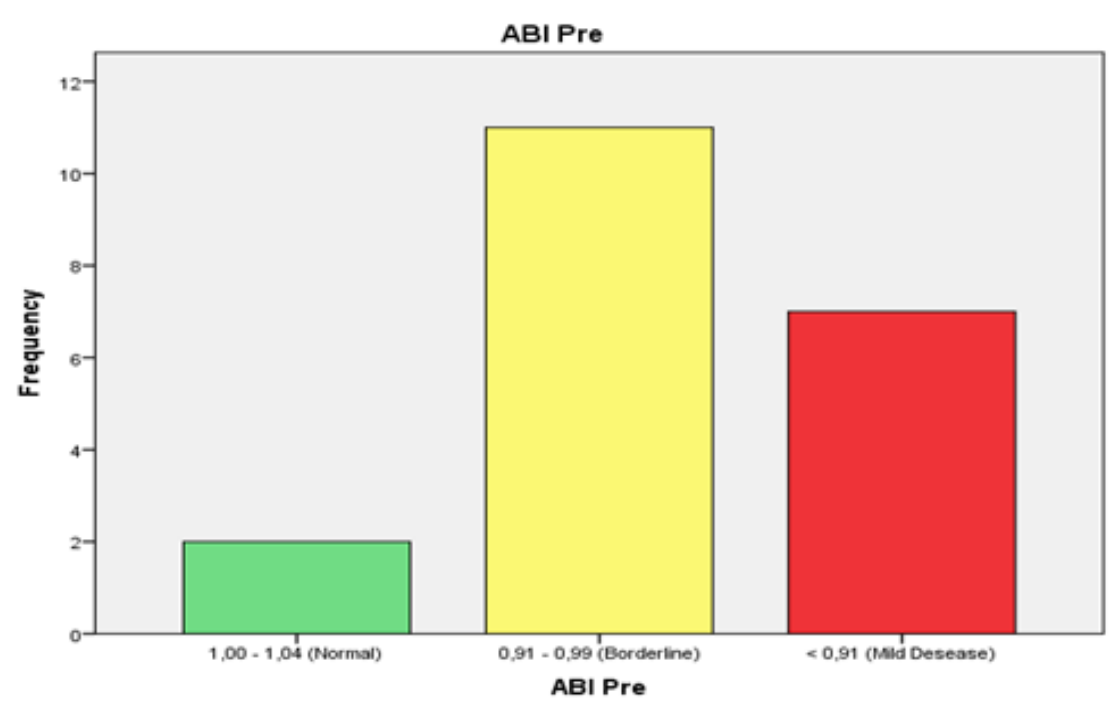


Bagan 1 Menunjukkanbahwa sebelum diberikan intervensifoot massageresponden dengan nilai ABI normal sebanyak 2 orang (10.00\%), borderline atau batasan perfusi sebanyak 11 orang $(55.00 \%)$ dan yang mengalami gangguan sirkulasi ringan sebanyak 7 orang $(35.00 \%)$.

Bagan 2. Deskripsi Nilai ABI Setelah intervensi (Post Test)Foot Massage pada Pasien DM Tipe 2

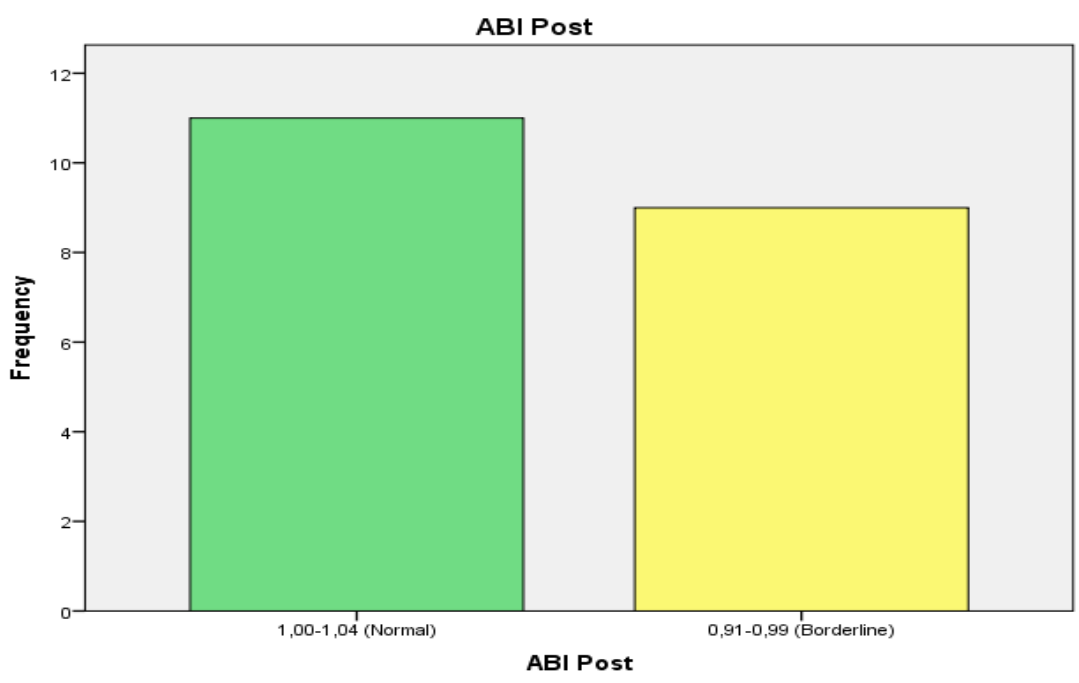

Bagan 2 Menunjukkan bahwa setelah diberikan intervensi foot massage responden dengan nilai $\mathrm{ABI}$ normal mengalami peningkatan yaitu sebanyak 11 orang $(55.00 \%)$, borderline atau batasan perfusi sebanyak 9 orang $(45.00 \%)$ dan tidak ada pasien yang mengalami gangguan sirkulasi.

\subsection{Hasil Analisis Sebelum (Pretest) dan Sesudah (Postest) pada kelompok intervensi pergerakan} sendi ektremitas bawah

Tabel 3. Deskripsi Nilai KGDs pada Pasien Diabetes

\begin{tabular}{clcccc}
\hline No & Nilai KGDs & Mean & Median & SD & Min - Maks \\
\hline 1 & Sebelum & 302.40 & 285.00 & 73.804 & $219-493$ \\
2 & Sesudah & 276.45 & 249.00 & 68.135 & $200-421$ \\
& Total & $\mathrm{N}=20$ & \\
\hline
\end{tabular}

Tabel 3 menunjukkan nilai KGDs pada pasien diabetes pada periode sebelum dan sesudah diberikan intervensi. Hasil pengukuran KGDs sebelum intervensi menunjukkan rata-rata nilai KGDs adalah $302.40 \mathrm{mg} / \mathrm{dL}$, median $285.00 \mathrm{mg} / \mathrm{dL}$, standar deviasi 73.804, dengan KGDs terendah yaitu $219 \mathrm{mg} / \mathrm{dL}$ dan nilai tertinggi $493 \mathrm{mg} / \mathrm{dL}$. Sedangkan hasil pengukuran KGDs sesudah intervensi menunjukkan rata-rata nilai KGDs adalah $276.40 \mathrm{mg} / \mathrm{dL}$, median 249.00 $\mathrm{mg} / \mathrm{dL}$, standar deviasi 68.135, dengan KGDs terendah yaitu $200 \mathrm{mg} / \mathrm{dL}$ dan nilai tertinggi 241 $\mathrm{mg} / \mathrm{dL}$.

Peningkatan kadar glukosa dalam darah dapat mempengaruhi penurunan nilai ABI, hal ini dikarenakan Keadaan hiperglikemia yang berlangsung lama dapat menyebabkan perubahan patologi pada pembuluh darah, akibat dari perubahan metabolisme, protein dan lemak sehingga mempercepat arterosklerosis pada pembuluh darah seperti aorta, arteri koroner, atau arteri yang memasok darah ke kaki dan otak penelitian yang dilakukan oleh Janitra (2018) menyatakan bahwa terdapat hubungan yang bermakna dengan kontrol glukosa darah dengan penurunan 
vaskularisasi perifer pada pasien DM, dimana responden dengan glukosa tidak terkontrol sebanyak 26 (38.8 \%) dan yang mengalami penurunan vaskularisasi perifer sebanyak 47,7 \% [9].

Lama menderita diabetes melitus juga dapat menyebabkan penumpukan glukosa dalam darahmengakibatkan kerusakan pada pembuluh darah, sehingga menimbulkan resiko terjadinya komplikasi yangbiasanya akan muncul pada 5-10 tahun, seperti penyakit pembuluh darah perifer dan nyeri neuropati. Sebuah studi menunjukkan bahwa insiden nyeri neuropatik lebih tinggi pada mereka yang berusia di atas 60 tahun, dan menunjukkan ABI>1,3. Nyeri neuropatik berhubungan dengan ABI abnormal pada 144 pasien $(64,2 \%)$ ddari 225 pasien pasien diabetes TIPE 1 dan 2 . Nilai yang signifikan secara statistik diperoleh pada pasien diabetes tipe 2 dengan lebih dari 10 tahun, 69 pasien dengan ABI yang berubah dan 25 pasien dengan ABI normal. Ada perubahan ABI $(<0,9)$ yang diamati pada $33 \%$ pasien diabetes tipe 1 dan pada $67 \%$ pasien diabetes tipe 2[10]. Terdapat penelitian yang tidak sejalan dengan penelitian ini yaitu penelitian yang dilakukan oleh Cahyono\& Purwanti (2019) yang menyatakan bahwa lamanya menderita diabetes melitus tidak mempengaruhi keabnormalan nilai ABI [11].

Tabel 4. Deskripsi Nilai ABI pada Pasien Diabetes

\begin{tabular}{lcllll}
\hline No & Nilai ABI & Mean & Median & SD & Min - Maks \\
\hline 1 & Sebelum & 0.91 & 0.90 & 0.04 & $0.87-1.00$ \\
2 & Sesudah & 0.98 & 1.00 & 0.05 & $0.89-1.07$ \\
\hline
\end{tabular}

Tabel 4 menunjukkan nilai ABI pasien diabetes sebelum dan sesudah diberikan intervensi. Hasil pengukuran menunjukkan rata-rata nilai ABI sebelum intervensi yaitu 0.91, median 0.90, standar deviasi 0.04, dengan nilai terendah pada 0.87, dan nilai tertinggi 1.00. Sedangkan Hasil pengukuran sesudah diberikan intervensi menunjukkan bahwa rata-rata nilai ABI 0.98, median 1.00, standar deviasi 0.05 , dengan nilai terendah pada 0.89 , dan nilai tertinggi 1.07 .

Bagan 3. Deskripsi Nilai ABI Sebelum Intervensi(Pre Test) Pergerakan Sendi Ekstremitas Bawahpada Pasien DM Tipe 2

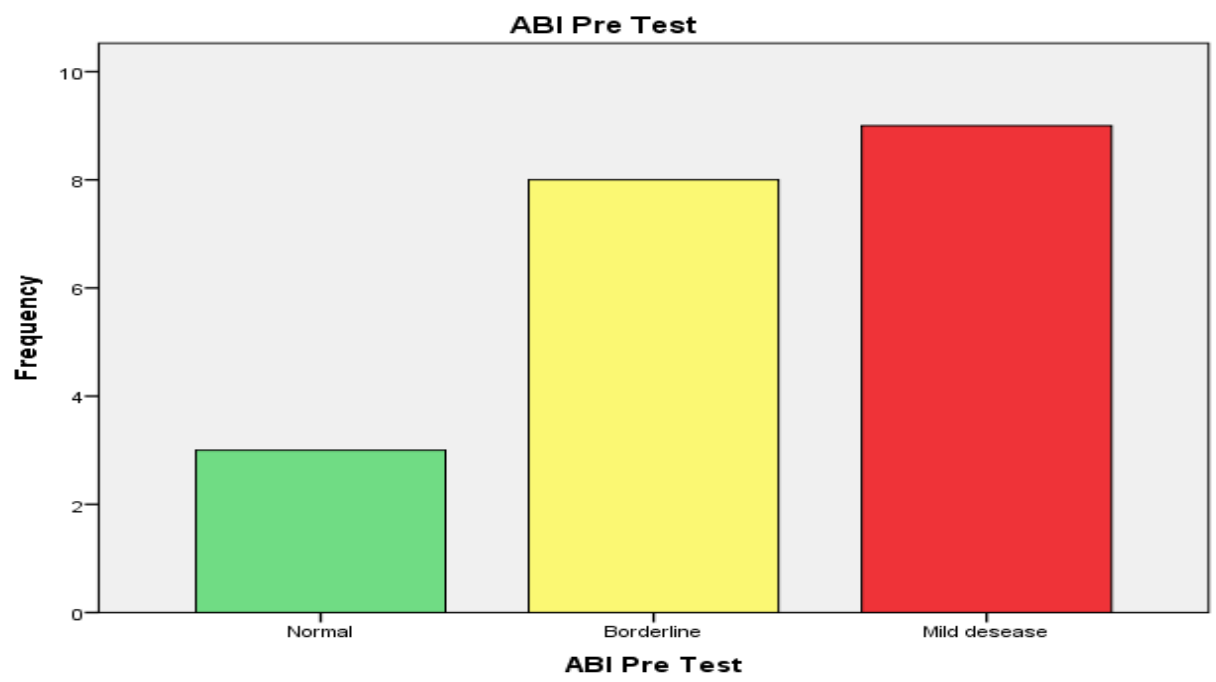

Bagan 3 menunjukkan sebelum diberikan intervensi pergerakan sendi ektremitas bawah responden dengan nilai ABI normal sebanyak 3 orang (15\%), borderline atau batasan perfusi sebanyak 8 orang (40\%), dan yang mengalami gangguan sirkulasi ringan sebanyak 9 orang (45\%). 
Bagan 4. Deskripsi Nilai ABI Setelah Intervensi (Post Test) Pergerakan Sendi Ekstremitas Bawahpada Pasien DM Tipe 2

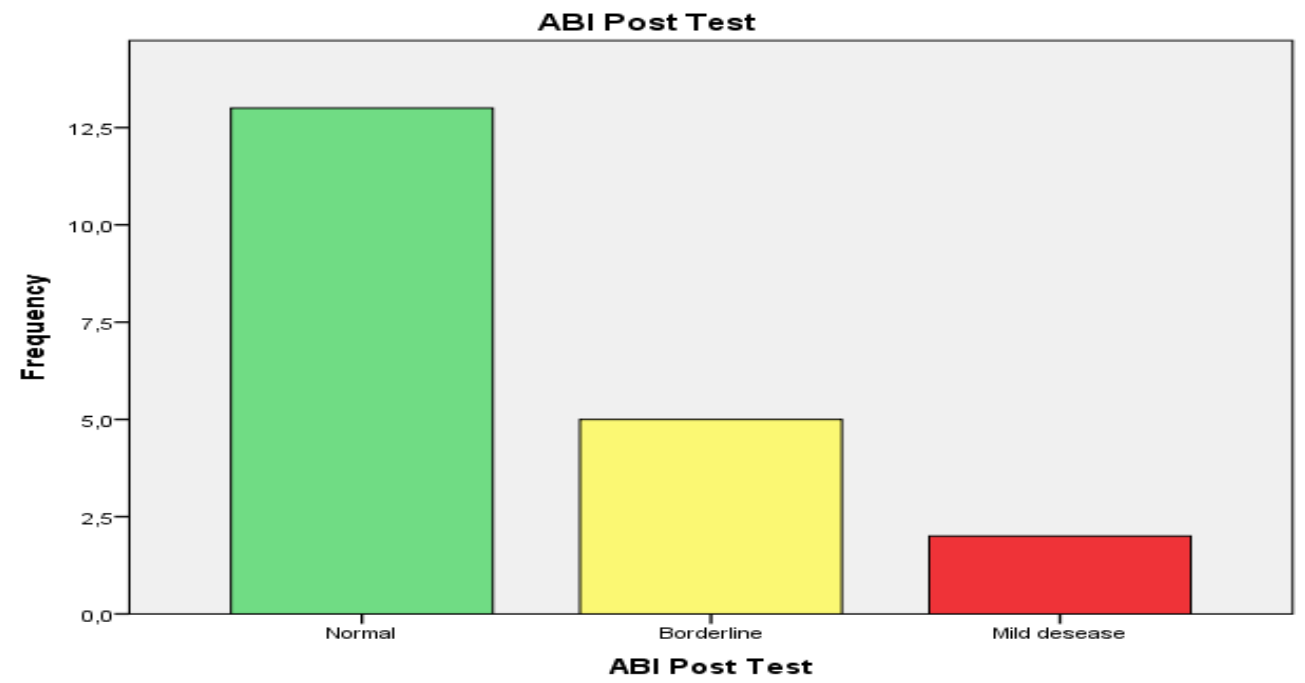

Bagan 4 menunjukkan sesudah intervensi pergerakan sendi ektremitas bawah, nilai ABI menjadi normal sebanyak 13 orang $(65.00 \%)$, borderline sebanyak 5 orang (25 $\%$ ) dan terdapat 2 pasien (10\%) masih mengalami gangguan sirkulasi ringan.

\subsection{AnalisisPerbedaan Nilai ABI Sebelum Dan Sesudah Dilakukan Foot Massage dan Pergerakan Sendi Ekstremitas Bawah}

Tabel 5. Perbedaan Nilai ABI Sebelum Dan Sesudah Diberikan Foot Massage dan Pergerakan Sendi Ekstremitas

\begin{tabular}{clccc}
\hline \multirow{2}{*}{ No } & \multicolumn{1}{c}{ Nilai ABI } & \multicolumn{2}{c}{ Mean Rank } & \multirow{2}{*}{ Nilai $\boldsymbol{p}$} \\
\cline { 3 - 4 } & & Sebelum & Sesudah & \\
\hline 1 & Kelompok Foot Massage & 0.00 & 9.50 & 0.00 \\
2 & Kelompok Pergerakan Sendi & 0.00 & 10.00 & 0.00 \\
& Ekstremitas Bawah & & & \\
\hline
\end{tabular}

Tabel 5 terlihat hasil uji statistik menggunakan uji Wilcoxon Signed Ranks test, yang menunjukkan bahwa terdapat perbedaan yang signifikan antara sebelum dan sesudah dilakukan intervensi foot massage terhadap nilai ABI $(p=0.00)$. Pada kelompok dengan intervensi pergerakan sendi ekstremitas bawah juga menunjukkan adanya perbedaan yang signifikan antara sebelum dan sesudah diberikan intervensi $(p=0.00)$.

Nilai $\mathrm{ABI}$ setelah dilakukannya intervensi foot massage menunjukkan rata-rata nilai $\mathrm{ABI}$ sebelum periode intervensi adalah 0.91,Sedangkan sesudah intervensi rata-rata nilai ABI menjadi 0.99. Hal ini menunjukkan bahwa tindakan yang dilakukan oleh responden memberikan dampak pada perubahan nilai ABI, yang kemudian juga dibuktikan secara statistik dengan uji Wilcoxon Signed Ranks test, dengan nilai $p=0.00(\mathrm{p}<0.05)$, sehingga dapat disimpulkan terdapat perbedaan nilai $\mathrm{ABI}$ sebelum dan sesudah dilakukan tindakan foot massage.

Hasil penelitian ini juga sejalan dengan penelitian yang dilakukan oleh Trianto dan Hastuti (2017) yang menunjukkan bahwa terdapat pengaruh senam kaki diabetes terhadap nilai ankle brachial index (ABI), uji paired $t$-test pengaruh senam kaki menunjukkan hasil nilai Sig. (2-tailed) nilai $A B I$ yaitu 0,001 atau $\mathrm{p}<0,05$, dengan perubahan rata-rata nilai $A B I$ sebelum dengan sesudah yaitu sebesar 0,05211. Senam kaki diabetes dapat meningkatkan nilai ankle brachial index (ABI) hal itu terjadi karena senam kaki membantu memperbaiki sirkulasi darah dan memperkuat otot-otot kecil kaki dan mencegah terjadinya kelainan bentuk kaki (Deformitas), dan mengatasi keterbatasan gerak sendi [12]. Penerapan foot massage selain bermanfaat bagi sirkulasi darah juga dapat meningkatkan keseimbangan, Timed Up \& Go (TUG) Test, functional reach test (FRT), penerapan 
plantar massage pada pasien DM T2 menyebabkan peningkatan nilai keseimbangan, mobilitas fungsional, dan jangkauan fungsional. Peningkatan keseimbangan tubuh dan mobilitas fungsional dapat menjelaskan peningkatan TUG [13].

Nilai ABI setelah dilakukannya intervensi pergerakan sendi ekstremitas bawah menunjukkan rata-rata nilai $\mathrm{ABI}$ sebelum periode intervensi adalah 0.91 , sedangkan sesudah intervensi rata-rata nilai $\mathrm{ABI}$ menjadi 0.98 . Hal ini menunjukkan bahwa tindakan yang dilakukan oleh responden memberikan dampak pada perubahan nilai ABI, yang kemudian juga dibuktikan secara statistik dengan uji Wilcoxon Signed Ranks test, dengan nilai $p=0.00(\mathrm{p}<0.05)$, sehingga dapat disimpulkan terdapat perbedaan nilai ABI sebelum dan sesudah dilakukan tindakan pergerakan sendi ekstremitas bawah. latihan fisik yang dilakukan secara regular juga termasuk kedalam program pencegahan sekunder faktor resiko komplikasi diabetes terutama terjadinya kaki diabetik dan amputasi, karena kaki diabetik dianggap sebagai komplikasi umum dari diabetes. Orang diabetes dapat mengalami sejumlah masalah kaki yang berbeda sebagai akibat dari kerusakan saraf dan pembuluh darah. Perawatan kaki diabetes yang efektif dapat meningkatkan kesehatan dan kualitas hidup pasien diabetes.

Departement of Rehabilitation Services the Ohio State University Wexner Medical Center (2012) menyatakan bahwa pergerakan sendi ankle sebaiknya dilakukan minimal 3 kali sehari dengan intesitas masing-masing gerakan 10 kali agar ini menunjukkan hasil yang maksimal [14]. latihan fisik yang serupa dengan pergerakan sendi ekstremitas bawah yaitu stimulasi otot gastroknemius, kontraksi yang efektif pada otot-otot betis (gastroknemius dan soleus) dapat meningkatkan kekuatan otot betis dan pompa otot betis (Calf pumping) yang akan menfasilitasi venous return dan dapat memperbaiki sirkulasi pembuluh darah vena. Latihan fisik telah terbukti dapat meningkatkan efisiensi pompa otot betis. home-based exercise seperti ROM Ankle sangat efektif dan memberikan efek terhadap penyembuhan vena ulcer, hal ini berkaitan dengan fungsi pompa otot betis. Pompa otot betis yang tidak aktifdianggap sebagaisalah satupenyebab utama insufisiensivena kronis yang kemudian mengarah pada ulserasi vena kaki [15].

pergerakan sendi juga dapat meningkatkan kekuatan otot kaki, fleksibilitas, tekanan plantar, dan kinematika dan kinetika pergelangan kaki selama gaya berjalan. sehingga dapat meningkatkan kemampuan pasien dalam melakukan aktivitas sehari-harinya serta meningkatkan kualitas hidup [16]. Latihan fisik lainnya yang serupa yaitu dengan menahan beban pada tumit selama 30 detik yang dilakukan secara rutin dapat menurunkan nilai TBI (toe-brachial index) dan tekanan jari kaki dari istirahat $103.00 \mathrm{mmHgke}$ pasca $98,50 \mathrm{mmHg}$, hal ini diakibatkan oleh penurunan resistensi pembuluh darah perifer [17].

\section{Kesimpulan}

Foot massage dan pergerakan sendi ekstremitas bawah dapat meningkatkan nilai ABI jika dilakukan secara kontinyu. Foot massage dan pergerakan sendi ekstremitas bawah dapat memperbaiki sirkulasi darah. Penelitian ini dapat menjadi masukan bagi pelayanan keperawatan untuk memberikan intervensi foot massage dan pergerakan sendi ekstremitas bawah kepada pasien DM Tipe 2 untuk mencegah komplikasi lebih lanjut.

\section{Referensi}

[1] World Health Organization, "Classification Of Diabetes Mellitus," Geneva: WorldHealth Organization, 2020.

[2] Kemenkes RI, "Tetap Produktif, Cegah, dan Atasi Diabetes Melitus,"Infodatin, 1-6. https://pusdatin.kemkes.go.id/folder/view/01/structure-publikasi-pusdatin-info-datin.html, 2020.

[3] Paneni, F., Beckman, J, A., Creager, M. A., \& Cosentino, F, "Diabetes and vascular disease: pathophysiology, clinical consequences, and medicaltherapy: part I," Eur. Heart J. 34, 2436- 2443, 2013. 
[4] Perkeni,"Pengelolaan dan Pencegahan Diabetes Melitus Tipe 2 di Indonesia,"Jakarta: Pengurus Besar Perkumpulan Endokrinologi Indonesia, 2019.

[5] American Diabetes Assosiation ,"Introduction : Standards of medical care in diabetes2020," Diabetes Care, 43, 1-2. https://doi.org/10.2337/dc21-Sint, 2020.

[6] Velescu A, Clara A, Peñafiel J, Ramos R, Marti R, Grau M, et al,"Adding low ankle brachial index to classical risk factors improves the prediction of major cardiovascular events," TheREGICOR study. Atherosclerosis; 241(2):357e63, 2015.

[7] Gibbs, B. B., Dobrosielski, D. A., Althouse, A. D., \& Stewart, K. J, "Effect of exercise training on ankle-brachial index in type 2 diabetes," Atherosclerosis. 230: 125-130, 2013.doi: 10.1016/j.atherosclerosis.2013.07.002

[8] Harmaya, "Pengaruh masase kaki terhadap sensasi proteksi pada kaki pasien diabetes melitus tipe II,"COPING (Community of Publishing in Nursing), 2(1), 2014.

[9] Janitra, F.E. Hubungan Kontrol Glukosa DarahDengan Penurunan Vaskularisasi Perifer Pada PasienDiabetes Mellitus.Nurscope.Jurnal Keperawatan Pemikiran Ilmiah.4 (3).18-22, 2018.

[10] Chevtchouk, L., Da Silva, M. H. S., \& Do Nascimento, O. J. M, "Ankle-brachial index and diabetic neuropathy: Study of 225 patients," Arquivos de Neuro-Psiquiatria, 75(8), 533-538, 2017. https://doi.org/10.1590/0004-282x20170084

[11] Cahyono, T.W., Purwanti, O.S. Hubungan Lama Menderita Diabetes Melitus Dengan Nilai Ankle Brachial Index. Jurnal Berita Ilmu Keperawatan, Vol. 12 (2), 2019, 65-71; p-ISSN:1979-2697.

[12] Trianto, A, Hastuti, R.T, "Pengaruh Senam Kaki Terhadap Nilai Ankle Brachial Index (ABI) Pada Pasien DM tipe II di Persadia Unit DR.Mewardi,"Jurnal Keperawatan Global,Volume 2, No 2, Desember 2017 hlm 62-111)

[13] Tütün Yümin, E., Şimşek, T. T., Sertel, M., Ankaralı, H., \& Yumin, M, "The effect of foot plantar massage on balance and functional reach in patients with type II diabetes," Physiotherapy Theory and Practice, 33(2), 115-123, 2017. https://doi.org/10.1080/09593985.2016.1271849

[14] Departement of Rehabilitation Services TheOhio State University Wexner Medical Center (2012). Ankle range of motion exercise.

[15] O’Brien, J., Edwards, H., Stewart, I., \& Gibbs, H. A. Home-based progressive resistance exercise programme for patients with venous leg ulcers: a feasibility study. Int Wound J, 2012.doi: 10.1111/j.1742-481X.2012.00995.x

[16] Monteiro, R. L., Sartor, C. D., Ferreira, J. S. S. P., Dantas, M. G. B., Bus, S. A., \& Sacco, I. C. N, "Protocol for evaluating the effects of a foot-ankle therapeutic exercise program on daily activity, footankle functionality, and biomechanics in people with diabetic polyneuropathy: A randomized controlled trial", BMC Musculoskeletal Disorders, 19(1), 2018. https://doi.org/10.1186/s12891-018-2323-

[17] Chuter, V. H, "How does a short period of exercise effect toe pressures and toe-brachial indices? A cross-sectional exploratory study," Journal of Foot and Ankle Research,11(1). 2018. https://doi.org/10.1186/s13047-018-0309-7. 